\title{
The bicentenary of the Royal College of Surgeons in Ireland 1784-1984
}

\author{
EOIN O'BRIEN
}

In 1984 the Royal College of Surgeons in Ireland celebrates the 200th anniversary of the granting of its charter by George III in 1784. To mark this historic occasion the council of the college under the president, Professor Eoin O'Malley, will meet on 6 March 1984 in the board room of the Rotunda Hospital, where the first council sat with its president, Samuel Croker King. The bicentenary will, moreover, be commemorated through the year by a series of scientific and cultural events. Though the surgeons of Ireland were later than the physicians in organising themselves as a profession, their origins date from the fifteenth century and the story of their development reflects the history of Irish medicine.

\section{The barber-surgeons and the physicians}

The first medical corporation to be established by royal decree in Britain and Ireland was in 1446, when Henry VI granted a charter to the Guild of the Art of Barbers, or Guild of St Mary Magdalene, for the promotion and practice of the art of chirurgery. ${ }^{1}$ In subsequent charters the apothecaries and periwig makers were incorporated in the same guild as the barbers and surgeons. Membership of the guild was by apprenticeship, which varied from five to seven years, followed by three years as a journeyman surgeon and two years' work as master, after which admission to the guild could be sought. No diplomas were granted, and those desiring a broader education had to travel to the universities of Europe.

In ancient Ireland physicians were attached to the clan or house of a chieftain. As with the surgeons, training of the hereditary physicians was mainly by apprenticeship, though many were well versed in the writings of the European universities and some may have attended these schools. The barber-surgeons and apothecaries together with the quacks and faith healers, of whom there were many, attended to the poor classes, whereas the university educated physicians cared for the well to do and steadfastly rejected any contact, professional or social, with their lowly surgical colleagues.

In 1591 Elizabeth I granted the charter founding the University of Dublin and Trinity College. Though the new university had the right to confer medical degrees, it did not do so until 1674, and it was not until 1711 that it actually established a medical school. In 1654 a remarkable physician, John Stearne, a native of County Meath and professor of Hebrew at Trinity College, founded the Fraternity of Physicians, which was granted a charter in 1667 incorporating it as the College of Physicians in Ireland with Stearne as its first president. ${ }^{2}$

Before the suppression of the monasteries by Henry VIII in 1542 Ireland had a number of hospitals, most of which were leper houses, but some of which were for the sick and infirm. Almost all were monastic institutes and none remained after the suppression. The state of the sick poor of the country, and in Dublin especially, was deplorable until 1718, when six altruistically minded surgeons established the Charitable Infirmary for the care of "the maim'd and wounded poor" and

The Charitable Infirmary, Dublin 1

EOIN O'BRIEN, FRCPI, FRCP, consultant physician in so doing initiated a programme of hospital development that was to be one of the more remarkable features of the Georgian era in Ireland.

\section{The Royal College of Surgeons}

In 1765 Sylvester O'Halloran, a Limerick born surgeon who had studied at Leyden and Paris, published proposals for "The Advancement of Surgery in Ireland." A younger surgeon, William Dease, strongly criticised the medical school at the University of Dublin, which taught only medicine while ignoring surgery altogether, and he applauded the English and French

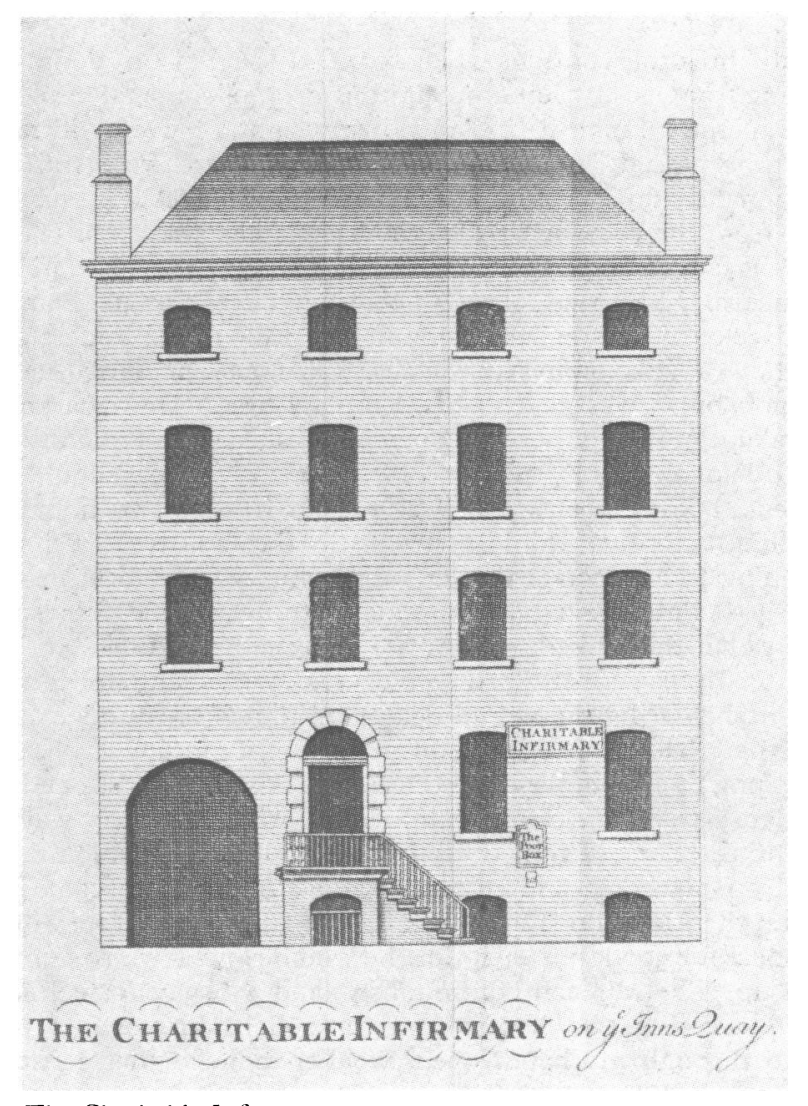

The Charitable Infirmary

surgeons who "by procuring a total separation from that preposterous union with the company of barbers" had been enabled to raise the standard of surgical practice. Samuel Croker King petitioned parliament unsuccessfully for a charter for the regulation of surgery in Ireland, and he then founded, with James Henthorn, the Dublin Society of Surgeons, which successfully obtained a charter in 1784 permitting the founding of a college not only to regulate the practice of surgery but also to make provision for surgical education.

The surgeons were now the proud possessors of a charter, but they had neither funds nor premises, and the professors had at first to teach in their own homes. In 1789 humble 
premises adjoining Mercer's Hospital were acquired, and here the "schools of the college" flourished, much of their success being due to the demand for army and navy surgeons for the Napoleonic wars. The need for larger premises was soon apparent, and George Renny, who as Director General of the Army Medical Department in Ireland had considerable influence with the government, obtained grants for the building of a new college on the site of the old Quaker burial plot in Stephen's Green. The new college opened in 1810 and its success was due not only to the facilities it offered (a lecture theatre, dissecting room, museum, and splendid board room and entrance hall) but to its good fortune in having among its staff some figures of exemplary talent and energy.

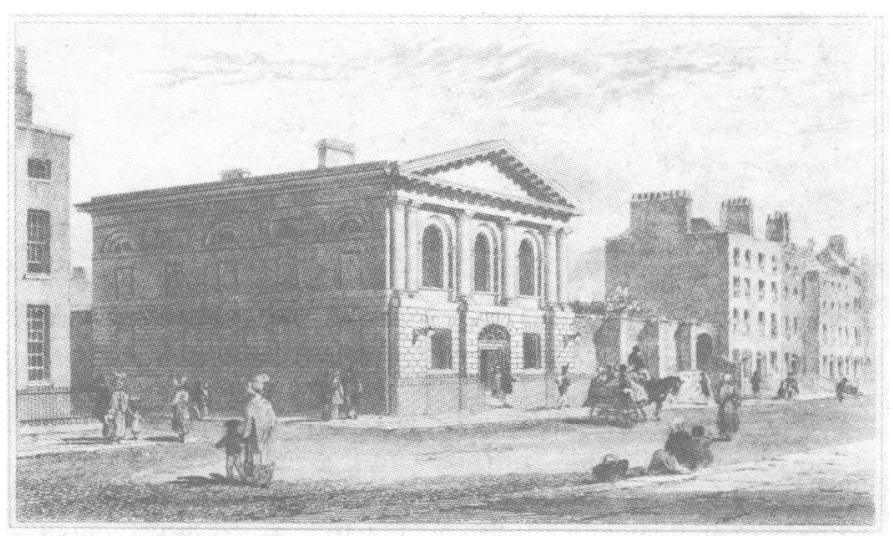

The Royal College of Surgeons in Ireland in 1821

Abraham Colles needs no introduction. As professor of anatomy and physiology and of surgery, as well as being president of the college on two occasions (1802 and 1830), he influenced its development and secured for it an international reputation. John Cheyne, a Scotsman who was linked eponymously with Stokes when the latter drew attention to Cheyne's account of the respiration associated with terminal illness, was professor of medicine. He was succeeded by Whitley Stokes, father of William, but deserving of commemoration in his own right as a physician with a philosophical outlook. In holding the chairs of medicine in both the college and later at the School of Physic at Trinity College he did much to advance the standards of medical education. It was not long before the college again found its premises inadequate, and in 1826 by a skilful architectural manoeuvre the front of the old college was incorporated in a larger structure, which remains to this day, its pediment flanked by the Greek deities Aesculapius, Minerva, and Hygeia. ${ }^{4}$

\section{The "Dublin School"}

Improved though the teaching of anatomy assuredly was, and beneficial though this may have been to the practice of surgery, there is ample evidence from published accounts that surgeons were blind to the inevitable consequences of many of their operations. Vivid though they are, few contemporary accounts quite convey the hopelessness of a Georgian operation as well as an unknown student's watercolour. The student was present in the drawing room of a fashionable Dublin house in 1817 when Rawdon Macnamara (a future president of the College of Surgeons) removed a tumour from the breast of one named Richard Power. This was performed under the watchful eye of the Surgeon General, Sir Philip Crampton (a past president of the college), whose boast it was that he could swim across Lough Bray, ride into town, and amputate a limb before breakfast. Needless to relate the unfortunate Power died shortly afterwards. Medical treatment was not much better, and many were the unfortunate patients who suffered greatly from the antiphlogistic remedies of their physicians-bleeding, purging, blistering, and starvation. ${ }^{5}$

The dawn of the Victorian era saw the stage set for what must be surely regarded as one of the most unlikely phenomena-the "Dublin School." Robert Graves together with William Stokes and Dominic Corrigan founded a movement that bequeathed to medicine not only a host of clinical descriptions bearing their names, but also the form of clinical bedside teaching with which we are familiar today; even more importantly, they refuted the barbaric antiphlogistic remedies of their predecessors.

This, however, is not the story of the Dublin School, but mention must be made of some of those surgeons associated with it. William Wilde, founder of the first ophthalmic hospital in Britain and Ireland, was a surgeon with a remarkable range of interests; John MacDonnell introduced anaesthesia in the Richmond Hospital in 1847, and his son Robert performed the first transfusion of human blood in the Charitable Infirmary in 1865; Francis Rynd introduced the hypodermic syringe in 1845; and Robert Adams, three times president of the College of Surgeons, is commemorated in the joint eponym with Stokes-a testimony to his considerable prowess at auscultation before Stokes introduced the stethoscope to Ireland.

\section{Towards a compleat doctor}

The old Guild of Barber-Surgeons approached the physicians in the early eighteenth century seeking a conjoint examination but was rejected. The College of Physicians, in fact, forbade its fellows and licentiates on oath to meet a surgeon in consultations. After founding their college the surgeons lost no time in incorporating chairs of not only surgery, anatomy, and physiology, but also of botany, midwifery, surgical pharmacy, chemistry and physics, and medicine, thus enabling their graduates to practise either surgery or medicine.

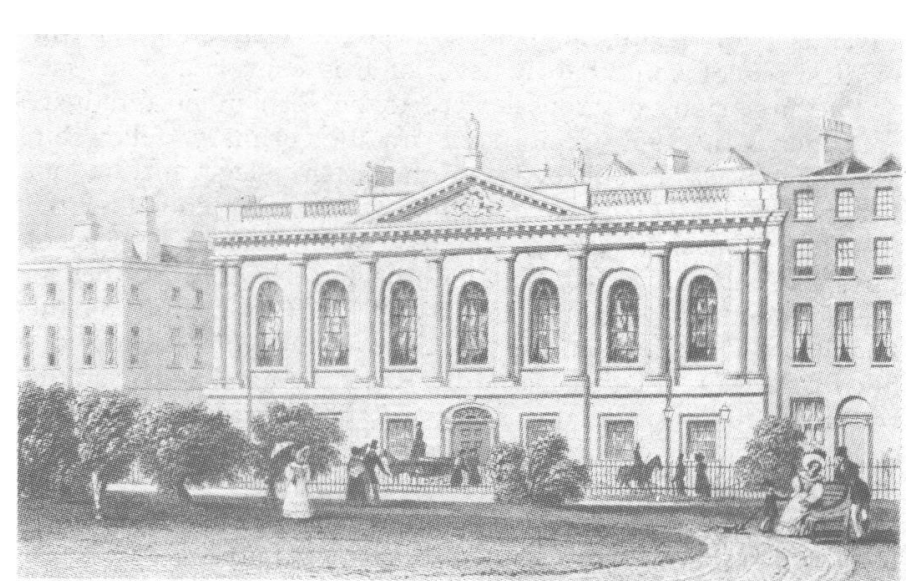

The Royal College of Surgeons in Ireland in 1826, after its enlargement.

In 1849 a chair of surgery was created at Trinity College, and nine years later the university instituted the degree of master in surgery. With the passing of the Medical Act of 1858, the College of Physicians made proposals to the College of Surgeons for cooperation in conducting their examinations. It was now the surgeons' turn to be high handed and they declined the offer, believing that because their curriculum included medicine and the allied subjects, an alliance with the physicians would not be to their advantage. An amendment to the Medical Act in 1886, however, made it imperative for all seeking admission to the Medical Register to have qualifications in medicine, surgery, and midwifery, and the conjoint licence of the Royal Colleges of Physicians and Surgeons of Ireland came into being and exists to this day. 
The College of Surgeons forged a less well known link with another institution that was to have importance in a later age. When the medical school of the Catholic University founded by John Cardinal Newman opened in Cecilia Street in 1855 the College of Surgeons accepted immediately its curriculum and allowed its students to sit for the licentiate, thus ensuring its survival. The nicety of historical reciprocity was achieved recently when the National University of Ireland (into which the Catholic University Medical School was incorporated at its foundation in 1909) responded to the college's desire to confer degree status on its graduates by declaring the college a recognised college of the National University of Ireland, and graduates now receive the licence as well as the degree of the National University.

\section{Postgraduate and academic endeavour}

When Dominic Corrigan and William Stokes retired from active participation in clinical medicine in the 1860 s the short lived Dublin School came to a close and Irish medicine entered a century of stagnation. Both undergraduate and postgraduate development in the college came to a standstill. Teaching in the medical school was conducted by part time professors whose only remit was to deliver a given number of lectures, and they lacked the academic vision of their counterparts in Britain and America, where professorial departments were devoted not only to teaching, but also to research. The medical school of the College of Surgeons was content to confer (with the College of Physicians) the conjoint licentiate, each body being concerned only with producing a competently trained doctor; neither showed any particular concern for academic prowess. It is hardly surprising, therefore, that during this period almost all of the graduates of the college were destined for general practice. Indeed, they could scarcely have done otherwise as the qualifying licence, lacking the academic status of a degree, effectively disqualified the graduates from academic advancement. In the early 1950s the college probably plumbed the lowest depths since its foundation, at which point, we can surmise with the advantage of historical perspective, the extinction of the medical school would hardly have come as a surprise to anyone.

The first signs of arousal were to be seen in postgraduate education. In 1951 reciprocity in the primary fellowship examination was established with the sister colleges in London, Edinburgh, and Glasgow and this was later extended to the Royal Australasian College and the South African College of Physicians and Surgeons. In 1959 the Faculty of Anaesthetists was founded, in 1961 the Faculty of Radiology, in 1963 the Faculty of Dentistry, and in 1974 the Faculty of Nursing, the first of its kind in these islands. Recent years have seen the college embark on many successful postgraduate activities, among which one of the most notable has been the postgraduate fellowship training programme.

If the 1960s augured poorly for the future of the college so too did that decade usher in an able administrator as registrarDr Harry O'Flanagan. His talents, energy, and diplomatic prowess were to sustain for nearly 20 years a resurgence of the college's confidence in itself. A succession of farseeing presidents supported by the members of council embarked on an ambitious building programme for a new medical school on a site adjoining the old college. This new school was opened in 1976 and provides facilities for the undergraduate education of the school's 700 students; these comprise a third from Ireland and equat proportions from developing and developed countries throughout the world. The new building also provides seminar, lecture, and recreational facilities for postgraduate functions and houses the college's faculties and professorial departments. Clinical teaching is conducted mainly in the two major teaching

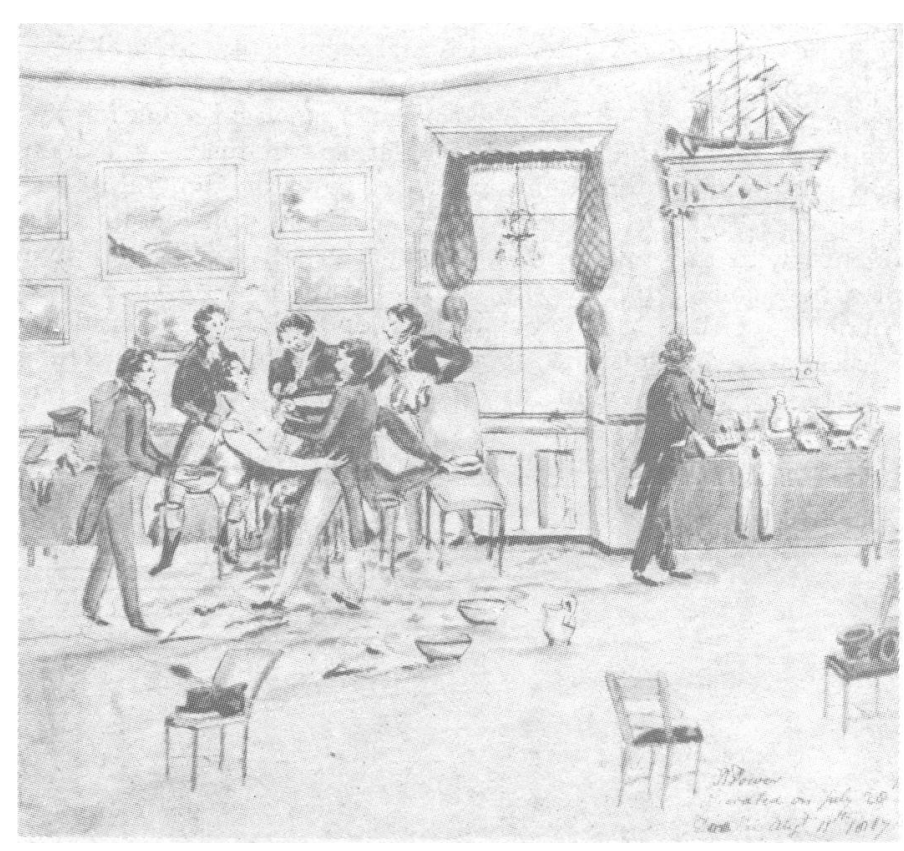

An operation in a Dublin drawing room in 1817. Watercolour by an unknown student.

hospitals, the Charitable Infirmary and St Laurence's Hospital, both shortly to be amalgamated in a recently completed 750 bedded hospital, on the site of which the college are financing a $£ 1 \mathrm{~m}$ clinical sciences building.

The College of Surgeons, which apart from a small annual government grant is independent and self financing, now moves into the closing years of the twentieth century having secured its undergraduate school and established postgraduate standards in surgery. If the writer of an essay for the 250th anniversary of this institute is to look forward to the future with the optimism of this homily, the college will need to have directed its energies and resources to the adequate staffing and financing of the major professorial departments, so that through research, and the contact that intellectual endeavour brings with workers in centres abroad (a feature so valued by the luminaries of the Dublin School), not only will its academic development be assured, but the Royal College of Surgeons in Ireland will once again hold pride of place in international medicine. From an analysis of two rich centuries of history the college can learn that its lowest hour was when chauvinistic complacency permitted the acceptance of mediocrity and its greatest moments, of which there have been a few, were when it reached for excellence.

I thank Mr David Davison, Pieterse-Davison International Ltd, Dublin, who took the photographs.

\section{References}

${ }^{1}$ Kirkpatrick TPC. History of the medical teaching in Trinity College Dublin and of the School of Physic in Ireland. Dublin: Hanna and Neale, 1912: 14-5.

-Widdess JDH. A history of the Royal College of Physicians of Ireland 16.54-1963. Edinburgh and London: $\mathrm{E}$ and $\mathrm{S}$ Livingstone, 1963:14-22.

${ }^{3}$ O'Brien E. The Georgian era, 1714-1835. In: O'Brien E, Crookshank A, Wolstenholme $\mathrm{G}$, eds. A portrait of Irish medicine: an illustrated history of medicine in Ireland. Dublin: Ward River, 1983:85-9.

${ }^{1}$ Widdess JDH. The Royal College of Surgeons in Ireland and its medical school. 3rd ed. Dublin: Royal College of Surgeons in Ireland, 1984:68.

5 O'Brien E. Conscience and conflict. A biography of Sir Dominic Corrigan 1802-1880. Dublin: Glendale Press, 1983:132-40. 